\title{
Knocking down Insulin Receptor in Pancreatic Beta Cell lines with Lentiviral-Small Hairpin RNA Reduces Glucose-Stimulated Insulin Secretion via Decreasing the Gene Expression of Insulin, GLUT2 and Pdx1
}

\author{
Jie Wang ${ }^{1}$, Wenyi Gu ${ }^{2, *(1)}$ and Chen Chen $1, *$ (i) \\ 1 School of Biomedical Sciences The University of Queensland, Brisbane 4072, Australia; \\ jiewang1986@yahoo.com \\ 2 Australian Institute for Bioengineering and Nanotechnology, the University of Queensland, \\ Brisbane 4072, Australia \\ * Correspondence: w.gu@uq.edu.au (W.G.); chen.chen@uq.edu.au (C.C.)
}

Received: 3 February 2018; Accepted: 21 March 2018; Published: 26 March 2018

\begin{abstract}
Type 2 diabetes (T2D) is a metabolic disorder characterized by beta cell dysfunction and insulin resistance in fat, muscle and liver cells. Recent studies have shown that the development of insulin resistance in pancreatic beta cell lines may contribute to beta cell dysfunction in T2D. However, there still is a lack of detailed investigations regarding the mechanisms by which insulin deficiency may contribute in diabetes. In this study, we firstly established a stable insulin receptor knockdown cell line in pancreatic beta cells INS-1 (InsR $\beta$ KD cells) using anti InsR $\beta$ small hairpin RNA (InsR $\beta$-shRNA) encoded by lentiviral vectors. The resultant InsR $\beta$ KD cells demonstrated a significantly reduced expression of InsR $\beta$ as determined by real-time PCR and Western blotting analyses. Upon removing glucose from the medium, these cells exhibited a significant decrease in insulin gene expression and protein secretion in response to $20 \mathrm{mM}$ glucose stimulation. In accordance with this insulin reduction, the glucose uptake efficiency as indicated by a ${ }^{3}[\mathrm{H}]-2$-deoxy-D-glucose assay also decreased. Furthermore, InsR $\beta K D$ cells showed a dramatic decrease in glucose transporter 2 (GLUT2, encoded by SLC2A2) and pancreatic duodenal homeobox (Pdx1) mRNA expression compared to the controls. These data collectively suggest that pancreatic beta cell insulin resistance contributes to the development of beta cell dysfunction by impairing pancreatic beta cell glucose sensation through the Pdx1- GLUT2 pathway. InsR $\beta$ KD cells provide a good model to further investigate the mechanism of $\beta$-cell dysfunction in T2D.
\end{abstract}

Keywords: Type 2 diabetes; RNA interference; shRNA; pancreatic beta cells; insulin resistance; pancreatic beta cell dysfunction; insulin receptor; insulin secretion; glucose uptake

\section{Introduction}

Diabetes is one of the fastest growing chronic diseases worldwide [1]. Type 2 diabetes (T2D) accounts for over $90 \%$ with more of the pre-diabetes population exhibiting an elevation of fasting glucose and/or impaired glucose tolerance [2]. Intermediate hyperglycemia can result from deficient insulin secretion and insulin resistance [3]. Impaired response to insulin action in fat, muscle and liver cells induces a breakdown of fat, a failure of glycogenesis, and excess insulin secretion at early stages of diabetes $[4,5]$. Long-term compensating insulin secretion to insulin resistance may eventually lead to pancreatic beta cell failure [6]. 
Previous studies have suggested that neither peripheral tissue insulin resistance nor glucolipotoxicity fully explain the onset of beta cell dysfunction showing a delayed and insufficient insulin section to hyperglycemia in T2D. The pancreatic beta cell insulin receptor knockout ( $\beta$ IRKO) mice [7] lose insulin secretion in response to glucose, suggesting insulin receptors in beta cells may play a role in beta cell dysfunction. However, deletion (knock out) of InsR expression results in a complete loss of insulin action through life, which is different from progressive impaired insulin action on beta cells. Other studies using a small interfering RNA (siRNA) to knockdown insulin receptor (IRKD) in MIN6 cells described a significant decrease in glucose-stimulated insulin secretion (GSIS) and a reduced cell proliferation [8,9]. The siRNA-induced gene silencing yielded only a short-term suppression with a rapid recovery. It is thus necessary to set up a long-term InsR knockdown model in vitro to investigate the molecular mechanism underlying pancreatic beta cell dysfunction.

Insulin signalling pathway regulates glucose transport and metabolism. The tyrosin kinase domain of InsR $\beta$ subunit plays a major role in InsR signal transduction $[10,11]$, thus silencing $\beta$ subunit of InsR gene in pancreatic beta cells is appropriate to clarify the contribution of pancreatic beta cell insulin resistance. The transport of glucose is predominantly conducted by GLUT2 in pancreatic beta cells. GLUT2 allows a parallel rise of pancreatic beta cell insulin secretion in response to an increase in blood glucose concentration [12-15]. The loss of GLUT2 expression was found in diabetic $\mathrm{db} / \mathrm{db}$ mice pancreatic beta cells, which could be restored by transplanting islets from normal mice to diabetic mice [16]. GLUT2-null mice displayed a loss of first (rapid) phase GSIS, which could be rescued by re-expression of GLUT2 in pancreatic beta cells [17].

Pdx1, a major regulator of GLUT2 expression, can bind to the GLUT2 transcription promoter $[18,19]$. Pdx1 expression is restricted to the $\beta$ and $\delta$ pancreatic cells and confers the downstream expression of pancreatic beta-cell-specific genes, such as insulin, islet amyloid polypeptide, and GLUT2. The binding of Pdx1 and Pdx1-recognized TAAT motif enhances the transcription of the GLUT2 gene [18,19]. Reduced Pdx1 expression results in a decline in GLUT2 expression [18,20,21]. In this study, we firstly set up a stable InsR $\beta$ knock-down beta cell line and then demonstrated a decreased GSIS in the cells through the reduction of GLUT2 and Pdx1 in the cells.

This InsR $\beta K D$ cell line thus provides a good model to further investigate the mechanism of $\beta$-cell dysfunction in T2D.

\section{Results}

\subsection{Cloning shRNAs into pLL3.7 Plasmid and Lentiviral Production}

The backbone of lentiviral transfer plasmid pLL3.7 and the cloning sites of Hap I and Xho I are shown in Figure 1A. The sequence and expected stem-loop structure of InsR shRNA were shown in Figure 1B,C. The cloning results were confirmed by both agarose gel electrophoresis (Figure 1D) and sequencing (Figure 1E). The DNA fragment cut from the pLL3.7 vector with no insert gave a band of $450 \mathrm{bp}$, while the digest containing the InsR $\beta$ shRNA gave a slight bigger band of 500 bp (Figure 1D). The sequencing results confirmed the insert of shRNA-3 was correct (Figure 1E). Lentiviruses carrying InsR $\beta$ shRNAs and control shRNA 7-14 were produced by co-transfection of 293T cells with transferring plasmid and packaging plasmids as previously reported [22]. 

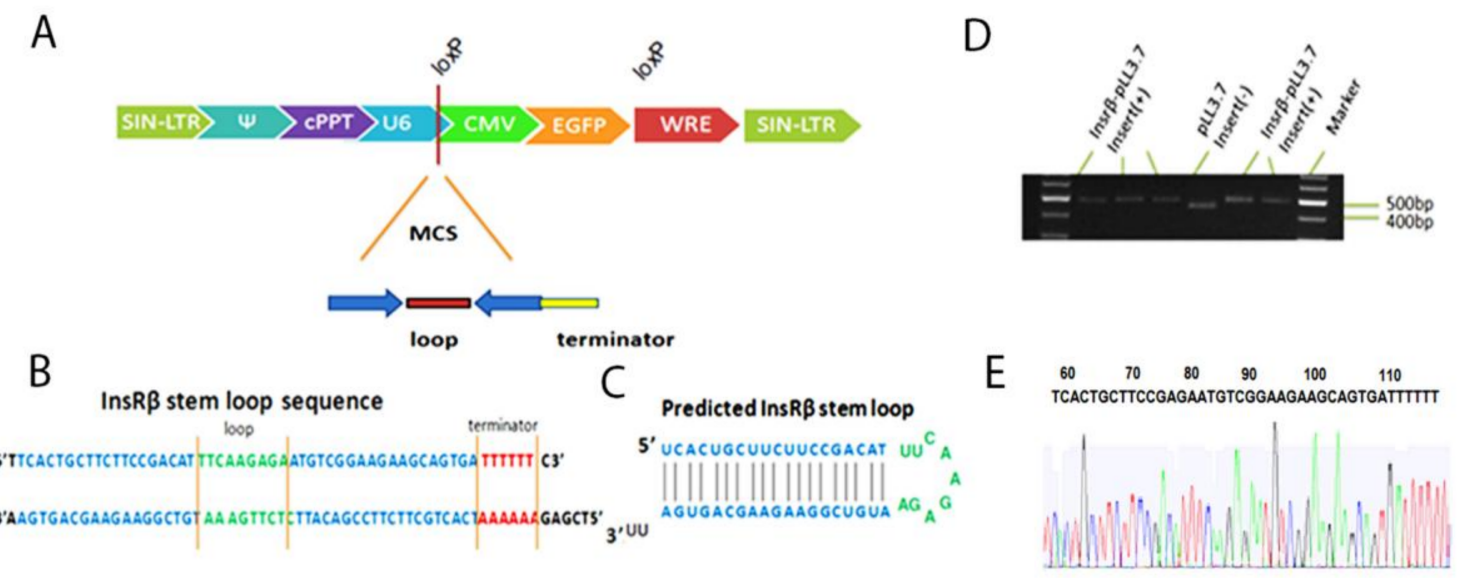

Figure 1. Lentiviral vector and predicted InsR $\beta$ shRNAs. (A) The linear structure of pLL3.7; the shRNA expression cassette is under the control of U6 promoter and eGFP gene is under the CMV promoter. (B) The annealed shRNA expression cassette. (C) The finished stem-loop structure of a representative shRNA. (D) Agarose gel electrophoresis shows a $500 \mathrm{bp}$ band cut from a positive InsR $\beta$-pLL3.7 while band cut from pLL3.7 was $450 \mathrm{bp}$. (E) Sequencing results confirms the inserted shRNA-3 sequence is correct.

\subsection{Establishment of Stable Insulin Receptor Knocking down Cell Line}

INS-1 cells were transduced with LV-InsR $\beta$ shRNAs and LV-7-14 shRNA and examined under a fluorescence microscope (lentiviral vector carries eGFP gene). Under UV light, successfully transduced INS-1 cells showed green fluorescence (Figure 2). Compared to control INS-1 cells, the transduced INS-1 cells maintained the same morphological characteristics (Figure 2). After proliferation of cells to more than 80\% confluence, GFP-positive cells (around 50-60\%) were sorted by FACS, and the sorted cells were kept in culture for one month to monitor the decline of lentiviral vector. After one month and about eight passages, the sorted cells were still highly GFP-positive (Figure 3), which suggested that transduced INS-1 cells were genetically stable and can be used in the following experiments.

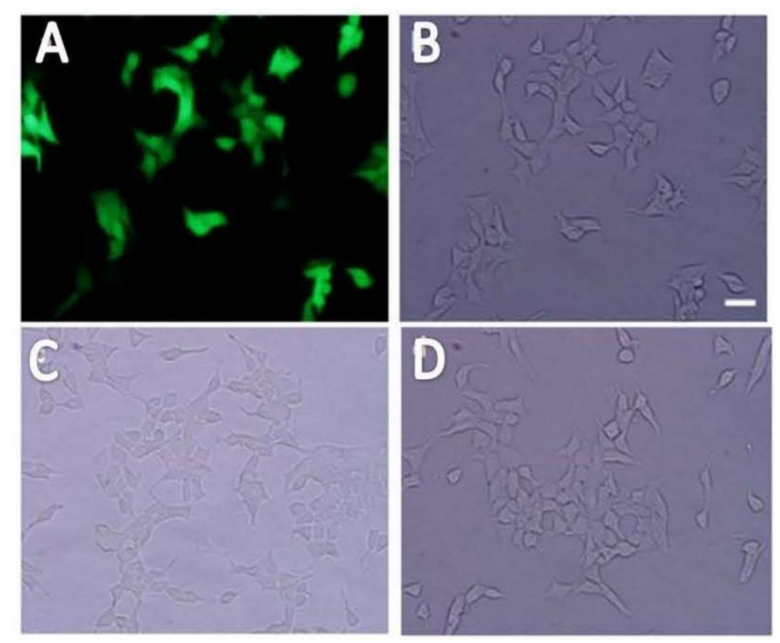

Figure 2. The morphology of transduced INS-1 cells. The transduced INS-1 cells showed strong green fluorescence (A) under a fluorescent microscope. The same view of the cells under white light field (B) show the cell morphology of transduced cells, indicating most of the cells were GFP-positive. From the view of morphology under the light microscope, the control un-transduced INS-1 cells (C) and InsR $\beta$ KD INS-1 cells (D) were no much differences. The scale bar is $50 \mu \mathrm{m}$ and all images share the same scale. 


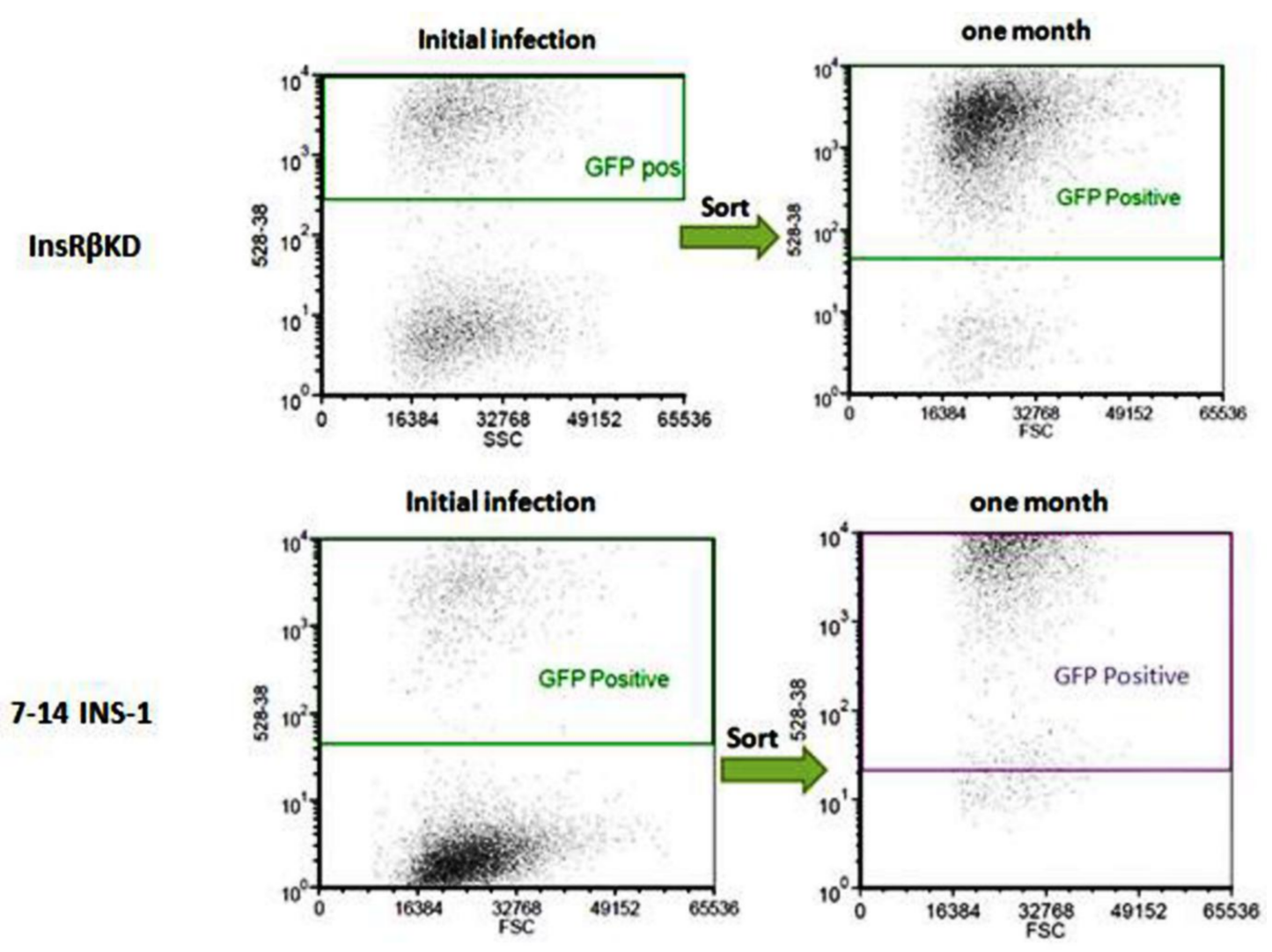

Figure 3. The stability of transduced INS-1 cells. After initial transductions of INS-1 cells with lentiviruses, GFP positive cells were sorted by FACS (left panels). After one-month culture of the positive cells, the InsR $\beta$ KD and LV-7-14-INS-1 cells show high percentages of GFP-positive (right panels), suggesting the transduction is stable.

\subsection{Confirmation of Gene Silence}

The InsR expression was firstly analysed by qPCR and Western blot in stable transduced cell lines. Data from qPCR showed a significant reduction ( $80 \%)$ of InsR mRNA expression in InsR $\beta$ KD cells (Figure 4A), compared to LV-7-14 transduced and non-transduced INS-1 cells. No significant decrease of InsR mRNA expression was found between the controls (Figure 4A). InsR $\beta$ KD cells also showed a significant reduction in InsR protein level, while no difference was observed between LV-7-14 transduced cells and INS-1 cells (Figure 4B,C). These data suggest that InsR protein levels are consistent with mRNA expression profiles (Figure 4B) and that specific gene silence has been achieved in the stable cell line InsR $\beta K D$. As shRNA-3 showed a better knocking down results than other sequences, InsR $\beta K D$ cells from this shRNA were used in the following experiments.

To exclude off-target effects of the shRNA, the expression of InsR $\alpha$ was measured by qPCR. Data obtained from qPCR showed a slight (non-significant) reduction (around 10\%) of InsR $\alpha$ mRNA expression in InsR $\beta$ KD cells (Figure 5A). Compared to INS-1 cells and LV-7-14 INS-1 cells, no significant decrease of InsR $\alpha$ mRNA expression was found (Figure 5A). 
A

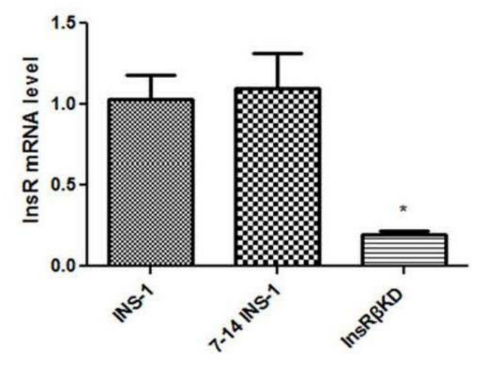

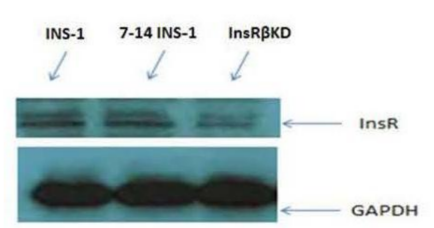

C

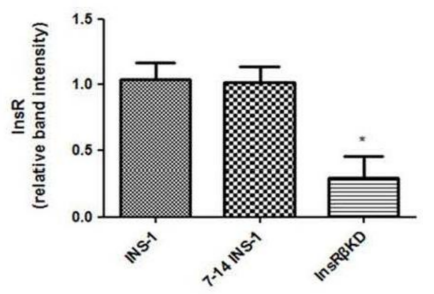

Figure 4. InsR expression in transduced cells. (A) qPCR result of measuring InsR mRNA levels in the 3 cell lines. The quantity level was firstly normalized to that of endogenous control glyceraldehyde 3-phosphate dehydrogenase (GAPDH) and then expressed relative to that in INS-1 cells. (B) A representative Western blot analysis of InsR protein levels in INS-1, 7-14 INS-1, and InsRßKD cells. GAPDH protein was similarly analysed as the loading control. (C) The densitometry analysis of band intensities of InsR relative to these of GAPDH. * $p<0.05, n=3$.

A

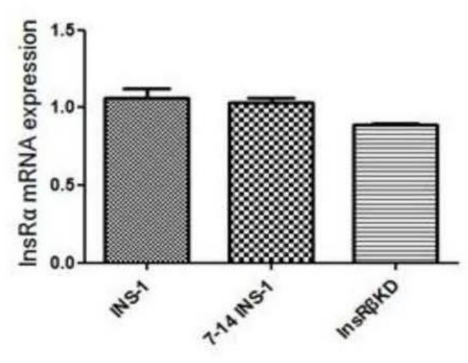

C

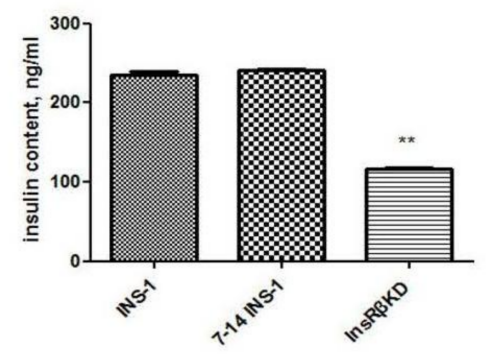

B

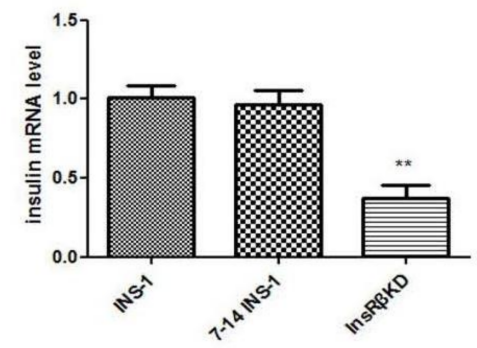

Figure 5. InsR $\alpha$ and insulin mRNA expression, and insulin content in transduced cells. InsR $\alpha(\mathbf{A})$ and insulin (B) mRNA expressions were measured using qPCR. The mRNA expressions were normalized to that of GAPDH and then to that of INS-1 cells. (C) ELISA result of insulin levels in INS-1, 7-14 INS-1, and InsR $\beta$ KD cells. InsR $\beta$ KD cells showed a reduction of insulin levels compared to the controls. $* * p<0.01, n=3$. 


\subsection{Reduced Insulin Expression and GSIS in InsR $\beta K D$ Cells}

To investigate the effect of InsR knock-down on insulin production, insulin mRNA expression, insulin content, and GSIS were assessed in transduced cells. qPCR analysis showed that insulin mRNA expression in InsR $\beta K D$ cells declined relative to that in control cells (Figure 5B). A corresponding result was obtained from insulin content analysis, which indicated a $50 \%$ reduction of insulin content in InsR $\beta K D$ cells in normal glucose culture conditions (Figure 5C). To assess the GSIS, cells were serum-starved in KRB buffer with $2 \mathrm{mM}$ glucose for $45 \mathrm{~min}$ and then treated with different concentrations of glucose or $25 \mathrm{mM} \mathrm{KCl}$. Insulin assay results revealed that all cells showed a dose-dependent increase of GSIS and at their highest levels with $25 \mathrm{mM} \mathrm{KCL}$ treatment (Figure 6A). InsR $\beta K D$ cells released less insulin in response to the stimulation of high concentration glucose at $20 \mathrm{mM}$ glucose or $25 \mathrm{mM} \mathrm{KCl}$ (Figure $6 \mathrm{~A}$ ). At $2 \mathrm{mM}$ of glucose, there was no difference observed between InsR $\beta \mathrm{KD}$ cells and the controls (Figure 6A).
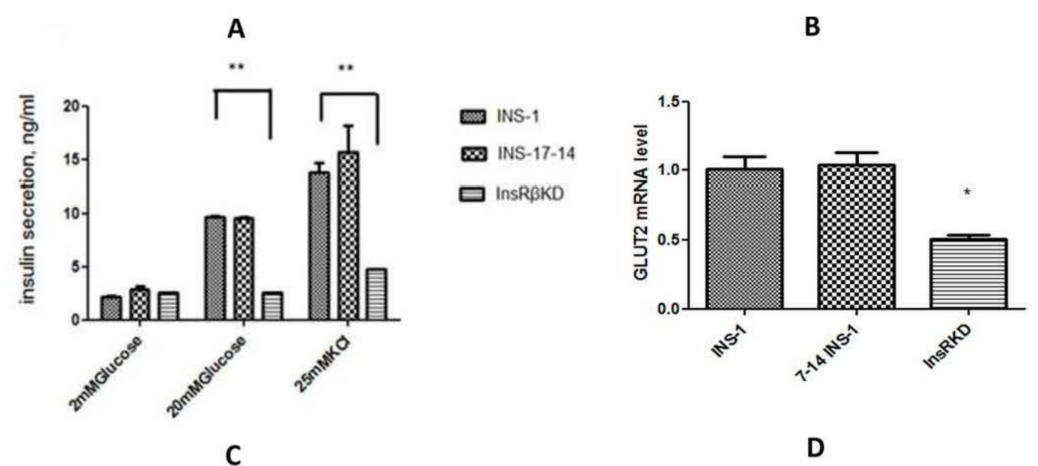

INS-1 7-14INS-1 InsRßKD
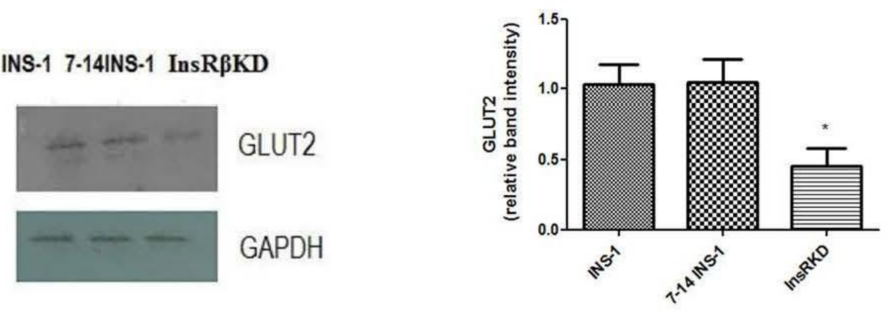

Figure 6. GSIS and GLUT2 expression in transduced cells. (A) ELISA results of insulin secretion induced by 2 and $20 \mathrm{mM}$ glucose and $25 \mathrm{mM} \mathrm{KCl}$ in INS-1, 7-14 INS-1, and InsR $\beta K D$ cells. Compared to controls, InsR $\beta$ KD cells showed significantly reduced insulin secretion at $20 \mathrm{mM}$ glucose and $25 \mathrm{mM}$ $\mathrm{KCl}$ stimulations. (B) GLUT2 mRNA expression by qPCR analysis, which was normalized to GAPDH expression and then to that of INS-1 cells. (C) A representative result of Western blot analysis for GLUT2 protein expression. (D) The densitometry analysis of band intensity of GLUT2 relative to GAPDH. ${ }^{*} p<0.05,{ }^{* *} p<0.01, n=3$.

\subsection{Reduced Glucose Influx through GLUT2 and Pdx1 Expression in InsR $\beta K D$ Cells}

To explore the mechanism underlying the reduced GSIS in InsR $\beta$ KD cells, GLUT2 mRNA expression was measured by qPCR. The results showed a decrease of GLUT2 mRNA expression in InsR $\beta K D$ cells compared to the controls of INS-1 and LV-7-14 INS-1 cells (Figure 6B). Western blot data further confirmed the reduced GLUT2 expression in InsR $\beta$ KD cells after InsR knock-down (Figure 6C,D). Glucose transport activity was assessed by measuring the radioactivity of ${ }^{3}[\mathrm{H}]$-2-deoxyglucose uptake into the cells. To ensure the measured glucose uptake mediated by GLUT2 translocation from cytosol to membrane, a group of cells were treated with cytochalasin $B$, an inhibitor of actin filament-dependent GLUT2 translocation. The subtraction of cytochalasin B-treated group counts from cytochalasin B-free group counts yielded the actual radioactivity of ${ }^{3}[\mathrm{H}]-2$-deoxyglucose uptake mediated by GLUT2. Compared to samples harvested from INS-1 cells, samples from InsR $\beta$ KD 
cells showed a significant reduction of radioactivity, which reflected a reduction of glucose uptake in InsR $\beta K D$ cells (Figure 7A). To clarify the contribution of the insulin signalling pathway to the decline in GLUT2 expression and glucose uptake, Pdx1 mRNA expression level was analysed by qPCR. A significant reduction of $\mathrm{Pdx} 1$ expression in InsR $\beta$ KD cells was observed, compared to $\mathrm{Pdx} 1$ expression levels in controls (Figure 7B).

A

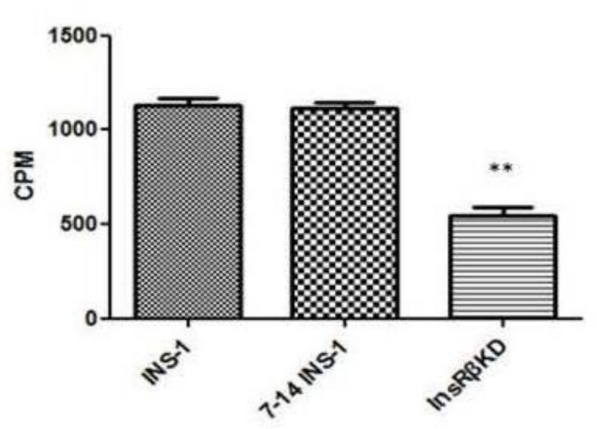

B

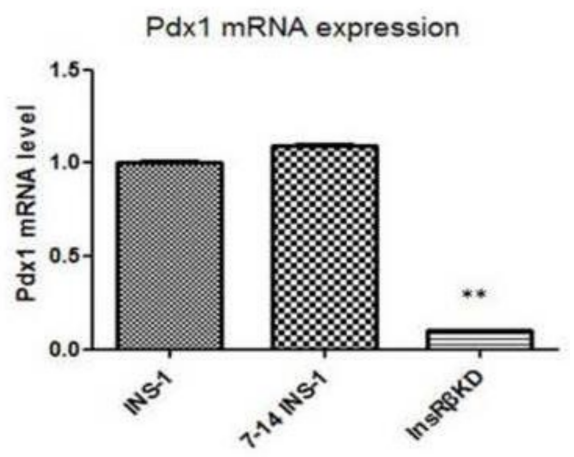

Figure 7. Radioactive 2-deoxyglucose uptake and Pdx1 expression in transduced cells. (A) Radioactivity of radioactive 2-deoxyglucose uptake expressed as CPM by a microplate scintillation counter. These results were then expressed relative to those in INS-1 cells. (B) The Pdx1 mRNA levels by qPCR analysis that was normalized to those of GAPDH and then to INS-1 cells. ${ }^{* *} p<0.01, n=3$.

\section{Discussion}

In this study, we have established an insulin-resistant pancreatic beta cell model using a lentiviral-mediated RNA interference technique. Gene expression analysis (Figure 4A,B) indicated that the designed shRNA specifically induced a reduction of InsR expression. Moreover, the transduction effect in FACS-purified cells was stable over one month and more than eight passages with GFP as a marker of successful transduction (Figure 3). Furthermore, cell morphology indicated no significant cytotoxic effects (cell death) caused by the lentiviral transduction as previous reports [23,24]. In addition, stable expressions of InsR $\alpha$ and GAPDH were also measured to exclude the off-target effects, while the expression of InsR $\beta$ was significantly reduced to around $20 \%$ of that in control INS- 1 cells (Figures 4 and 5A). This indicates that InsR $\beta$ shRNAs are highly specific with little off-target effects.

This lentiviral shRNA-induced gene silencing technique in pancreatic beta cell lines has the following advantages: (1) lentiviruses can efficiently infect mammalian cells; (2) lentiviruses can integrate into the host cell genome, and hence, provide a stable expression of the shRNA; (3) lentiviruses can be used to express multiple shRNAs simultaneously; and (4) the third generation lentiviruses are safe to use and are not replication-competent viruses [25-28]. Our study not only established InsR $\beta$ KD cells as an insulin-resistant pancreatic beta cell model but also introduced lentivirus-mediated shRNA as an efficient way for long-term target gene silencing cells. This kind of LV-InsR $\beta$ is expected to be a useful tool for further studies of insulin resistance.

There have been many in vivo as well as in vitro studies attempting to address the question of whether insulin secreted from pancreatic beta cells regulates its own synthesis and/or secretion with conflicting results [29-33]. In the present study, suppressing the insulin receptor resulted in a reduction in insulin gene expression (Figure 5B). Activation of insulin gene transcription depends on the interactions of multiple nuclear proteins on the insulin gene promoter to build a transcriptional activation complex. Many transcription factors have been found to act upon the insulin promoter region, such as Pdx1, MafA, and Beta2 (Neuro D). Pdx1 not only enhances the formation of insulin transcriptional activation complex by binding to the A3/4 region of the insulin promoter but also 
activates insulin gene transcription by cooperating with the basic helix-loop-helix (bHLH) proteins (such as Beta 2 and E47) that bind to the E1 site of insulin promoter [34-38]. In the present study, $\mathrm{Pdx} 1$ was significantly reduced in InsR $\beta K D$ cells, suggesting that $\mathrm{Pdx} 1$ is involved in the reduced insulin expression in insulin-resistant $\beta$-cells. The mechanism by which MafA participates in insulin transcription includes binding to and synergizing with Pdx1, Beta $2[39,40]$. These beta cell specific transcription factors interact with each other to tightly control insulin gene expression in a coordinated and synergistic manner.

As one of the early symptoms of beta cell failure in T2D, impaired GSIS was found in InsR $\beta K D$ cells (Figure 6A). The first phase GSIS occurs mainly at the level of exocytosis, which results from an increase in the ATP:ADP ratio, the closure of $\mathrm{K}_{\text {ATP }}$ channels causing cell membrane depolarization, $\mathrm{Ca}^{2+}$ influx and insulin release from readily releasable pool. When T2D progresses, total insulin secretion becomes insufficient leading to significant hyperglycemia. In the present study, the loss of insulin secretion at high concentrations of glucose stimulation indicated a reduced glucose metabolism rate and potential defects in cell membrane electrophysiological properties, in addition to deficient insulin. In the present study, the role of glucose transport was assessed and investigated.

The uptake of glucose into pancreatic beta cell plays a key role in the control of GSIS. Glucose uptake by pancreatic beta cells is mediated by GLUT2 and its deficiency is thought to causing diabetes. Mutational analyses of the coding region of the GLUT2 gene have been performed without consistent finding of linkage or association with T2D [41-45]. The present study provides the supporting evidence that GLUT2 expression plays a crucial role in the regulation of insulin secretion in the pancreatic beta cell line. The contribution of GLUT2 deficiency in the loss of GSIS was further confirmed by glucose uptake assays designed specifically to measure GLUT2-induced glucose influx (Figure 7A). In insulin-resistant InsR $\beta$ KD pancreatic beta cell line, GLUT2 deficiency may contribute to pancreatic beta cell failure.

An element thought to control GLUT2 expression is Pdx1, which has been addressed in the present study. Gene expression assay indicated a dramatic decline of $\mathrm{Pdx} 1$ gene expression in InsR $\beta K D$ cells (Figure 7B), which suggested that Pdx1 may play a role in the down-regulation of GLUT2 in insulin-resistant pancreatic beta cells. Taken together, Pdx1-GLUT2 may be one of the signalling pathways underlying pancreatic beta cell-insulin-resistance-induced beta cell dysfunction.

To conclude, normal InsR signals in beta cells are essential to maintain normal cell function. If insulin resistance or disturbance of InsR occurs, GSIS-related signalling pathways may be affected and $\beta$-cell dysfunction may occur, including disturbances in insulin synthesis and secretion. For disturbance in GSIS, Pdx1-GLUT2 and subsequent glucose uptake are involved.

\section{Materials and Methods}

\subsection{Small Hairpin RNA (shRNA) Design, Cloning and Sequencing}

We designed 4 shRNAs based on Rattus norvegicus InsR $\beta$ (InsR $\beta$ ) mRNA sequence (Gene ID: 24954) following the guidelines reported previously [22,46,47]. The shRNA expression cassettes contained 19 nucleotide (nt) of the target sequence followed by the loop sequence (TTCAAGAGA), reverse complement to the $19 \mathrm{nt}$, stop codon for U6 promoter, and Xho cloning site:

-InsR $\beta-1:$ 5'TGATGACAGCAGAAATTGCCTTCAAGAGAGGCAATTTCTGCTGTCATCTTTTTTC;
-InsR $\beta-2:$ 5'TGAATGACGAGAGACATCTATTCAAGAGATAGATGTCTCTCGTCATTCTTTTTTC;
-InsR $\beta-3:$ 5'TTCACTGCTTCTTCCGACATTTCAAGAGAATGTCGGAAGAAGCAGTGATTTTTTC;
-InsR $\beta-4:$ 5'TGTTCGAGGACATGGAGAATTTCAAGAGAATTCTCCATGTCCTCGAACTTTTTTC.

These shRNA expression cassettes and their complementary strands were synthesized commercially (Sigma, Victoria, Australia) and annealed in the annealing buffer following a protocol previously described [47]. Briefly, the resulting double-stranded oligo DNAs were cloned into pLL3.7 plasmids at the Hap I and Xho I of the MCS sites (Figure 1A) through phosphorylation and ligation 
reactions. To check the insert, the plasmids were digested with XbaI and NotI (NEW ENGLAND, Biolabs ${ }^{\circledR}$, Ipswich, MA, USA) and then assessed by $2 \%$ agarose gel electrophoresis for the inserted fragment. The plasmids were also mixed with sequencing primer ( $\left.5^{\prime} C A G C A C A A A A G G A A A C T C A C C\right)$ and sent for sequencing (AGRF, Melbourne, Australia) to further confirm the inserted sequences. Because the plasmid also contains an eGFP gene, the transduction of the lentiviral vector can be monitor by fluorescent microscope or flow cytometer.

\subsection{Cell Lines and Maintenance}

INS-1 is a rat pancreatic tumor beta cell line, which retains normal GSIS within approximately 80 passages and possesses the same genotype and tissue markers (e.g., glucose transporters, glucokinase, insulin genes) of its parental tissue [48,49]. They were maintained in RPMI-1640 medium supplemented with $10 \%$ heat-inactivated fetal calf serum (FBS), $1 \mathrm{mM}$ sodium pyruvate, $50 \mu \mathrm{M}$ 2-mercaptoethanol, $10 \mathrm{mM}$ HEPES (all from Sigma-Aldrich ${ }^{\circledR}$, St. Louis, MI, USA), $100 \mathrm{IU} / \mathrm{mL}$ penicillin and streptomycin (Life Technologies ${ }^{\circledR}$, Carlsbad, CA, USA) in a $37{ }^{\circ} \mathrm{C}$ incubator with $5 \% \mathrm{CO}_{2}$. INS- 1 cells were passaged every 5 days when they are $90 \%$ confluent. The $293 \mathrm{~T}$ cells (gift from Rod Minchin, University of Queensland) were maintained in Dulbecco's Modified Eagle's Medium (Life Technologies ${ }^{\circledR}$, Carlsbad, CA, USA) supplemented with 10\% FBS, $100 \mathrm{IU} / \mathrm{mL}$ penicillin and $100 \mathrm{\mu g} / \mathrm{mL}$ streptomycin in a $37^{\circ} \mathrm{C}$ incubator with $5 \% \mathrm{CO}_{2}$.

\subsection{Production of Lentiviruses and Transduction of INS-1 Cells}

The transferring plasmid pLL3.7 with inserts and packaging vectors (pVSVG, pRSV-REV, and pRRE) were extracted from DH5 $\alpha$ E. coli culture with HiPure Plasmid Maxiprep Kit (Life Technologies ${ }^{\circledR}$, Carlsbad, CA, USA). Twenty $\mu \mathrm{g}$ transferring plasmid and $10 \mu \mathrm{g}$ of each packaging plasmid were co-transfected in $400 \mu \mathrm{L} 1.25 \mathrm{M} \mathrm{CaCl}_{2}, 1.5 \mathrm{~mL} \mathrm{H}_{2} \mathrm{O}$ and $2 \mathrm{~mL} 2 \times$ HEPES buffered saline into 293T cells in T75 flasks. After four hours, the medium was removed and the cells were gentlely washed twice with PBS followed by adding $6 \mathrm{~mL}$ fresh medium for continuous culture. After $48 \mathrm{~h}$, the supernatant was harvested and concentrated by centrifugation for $50 \mathrm{~min}$ at $3000 \mathrm{rpm}$ at $4{ }^{\circ} \mathrm{C}$ using Vivaspin $20 \mathrm{~mL}$ tubes (Sartorius, Göttingen, Germany). The concentrated lentiviruses were stored at $-80^{\circ} \mathrm{C}$ freezer. Viral titers were determined as previously described [50]. We also produced LV-7-14 lentivirus as a negative control, the shRNA 7-14 was a non-effective shRNA and previously used as a negative control [51].

For transduction, INS-1 cells were plated in 6-well plates at the density of $5 \times 10^{5} /$ well and cultured overnight. Cells were then infected by $1 \times 10^{7}$ lentiviral particles in $500 \mu \mathrm{L}$ complete RPMI-1640/polybrene ( $8 \mu \mathrm{g} / \mathrm{mL}$, Sigma-Aldrich ${ }^{\circledR}$, St. Louis, MI, USA) for $60 \mathrm{~min}$ at $37^{\circ} \mathrm{C}$ before an additional $0.5 \mathrm{~mL}$ complete RPMI-1640/polybrene was added. After this, cells were incubated for another $24 \mathrm{~h}$, followed by the replacement of fresh complete RPMI-1640.

\subsection{Establishment of InsR $\beta K D$ Cells}

After transduction, the transduced cells were sorted for GFP positive cells using fluorescence-activated cell sorting (FACS). The sorted cells were cultured for a month or about 8 passages. These cells were checked for GFP expression again and used for assessing InsR $\beta$ expression. If the cells showed a sustained reduction of InsR $\beta$ we considered it was a stable cell line of InsR $\beta K D$ cells. The LV-7-14 transduced cell line was used as a negative control to reveal the potential off-target effects and viral toxicity on INS-1 cells.

\subsection{Quantitative PCR (qPCR)}

SYBR Green method was used for $\mathrm{qPCR}$ and specific primers were designed to ensure the monitored genes have equal amplification efficiency and the length of amplification products are similar. Data were analyzed by $2^{-\Delta \Delta C t}$ method as previously described $[52,53]$. For rat actin, GCAAATGCTTCTAGGCGGAC and AAGAAAGGGTGTAAAACGCAGC; for rat 
insulin $\mathrm{R} \alpha$, AAAGTTTGCCCAACCATCTG and GTGAAGGTCTTGGCAGAAGC; for rat insulin $\mathrm{R} \beta$, ATGGGACCACTGTACGCTTC and ACCACGTGATGACAGGTGAA; for PDX-1: AAACGCCACACACAAGGAGAA and AGACCTGGCGGTTCACATG; and for GLUT2: CAGCTGTCTCTGTGCTGCTTGT and GCCGTCATGCTCACATAACTCA.

\subsection{Western Blotting Analysis}

Total protein was extracted from cell culture and InR $\beta$ and GLUT2 proteins were quantified by Western blotting assay according to standard protocols. Briefly, cells were harvested by scrapping and lysed in Radio-immunoprecipitation assay (RIPA) buffer. The cell lysate was centrifuged for 5 min at full speed at $4{ }^{\circ} \mathrm{C}$ and the supernatant was transferred and stored at $-80^{\circ} \mathrm{C}$ for further analysis. Protein concentrations were determined using BCA assay kit (Thermo SCIENTIFIC, Waltham, MA, USA) according to manufacturer' $\mathrm{s}$ instructions. Total protein was separated by electrophoresis through $10 \%$ resolving gel and transferred to nitrocellulose membrane followed by primary and secondary antibody incubations. Immunodetection was performed according to ECL protocols instructed by the manufacturer.

\subsection{Insulin Assay}

In 24-well plates, $2 \times 10^{5}$ cells per wells were incubated for 3 days at $37^{\circ} \mathrm{C}$. Cells were washed twice with Krebs Ringer bicarbonate Buffer (KRB) containing 0.5\% BSA (Sigma-Aldrich ${ }^{\circledR}$, St. Louis, MI, USA). Cells were then pre-incubated in KRB $/ 0.5 \%$ BSA for $45 \mathrm{~min}$, followed by incubation in $\mathrm{KRB} / 0.5 \%$ BSA with $2 \mathrm{mM}$ glucose, $20 \mathrm{mM}$ glucose, and $25 \mathrm{mM} \mathrm{KCl}$ for $30 \mathrm{~min}$ at $37^{\circ} \mathrm{C}$. The supernatant was collected and stored at $-80{ }^{\circ} \mathrm{C}$ for insulin secretion analysis. In order to determine the remaining cellular insulin content, the cells were washed twice with ice-cold PBS and extracted with $1 \mathrm{~mL}$ acidified ethanol containing 75\% ( $v / v)$ ethanol plus $15 \mathrm{mM} \mathrm{HCl}$ overnight at $4{ }^{\circ} \mathrm{C}$ [8,48]. All samples were analysed using the Rat/Mouse Insulin ELISA kit (Merck Millipore North Ride, NSW, Australia) according to the manufacturer's instructions.

\subsection{Glucose Uptake Assay}

Different to glucose, ${ }^{3}[\mathrm{H}]$-2-deoxy-D-glucose has the 2-hydroxyl group replaced by hydrogen thus cannot be further metabolized by phosphoglucose isomerase and will accumulate in cells. The accumulation makes equilibration and isotope efflux less rapid than in the case with the 3-o-methylglucose, which is more convenient to be monitored for glucose influx [54-56]. To examine the GLUT2 mediated glucose influx, the cells are treated with the GLUT2 inhibitor, cytochalasin B, and the data collected from this group were set as the background [54,57]. In 24-well plates, $5 \times 10^{5}$ cells per wells were seeded and cultured overnight at $37^{\circ} \mathrm{C}$ before being used in the assay. To start, cells were washed twice with KRB/0.5\% BSA and pre-incubated in KRB/0.5\% BSA for $2 \mathrm{~h}$. Then cytochalasin B (Sigma-Aldrich ${ }^{\circledR}$, St. Louis, MI, USA) was added into the wells designed for background signal counting at a final concentration of $12.5 \mathrm{mM}$. The plate was then kept in the incubator for $1 \mathrm{~min}$. To initiate glucose uptake, ${ }^{3}[\mathrm{H}]$-2-deoxy-D-glucose (gift from A/Prof. Whitehead, Mater Medical Research Institute, Australia) was added to each well and the plate was incubated for 15 min at $37^{\circ} \mathrm{C}$. The plate was placed on ice to terminate the glucose transport and the buffer in wells was aspirated. The wells were washed four times with ice-cold PBS and dried on ice. To determine the radioactivity of cellular content, the cells were lysed by $1 \%$ Triton X-100 on a shaker for $15 \mathrm{~min}$. The cell lysate was collected and combined with scintillant (Ultima Gold ${ }^{\mathrm{TM}}$ Cocktails, PerkinElmer ${ }^{\circledR}$, Schwerzenbach, Switzerland) for radioactivity counting using a microplate scintillation counter [54,55].

\subsection{Data Analysis}

Data were analysed and shown as mean \pm S.E.M. Statistic analysis was conducted using one-way ANOVA. $p$ value $<0.05$ was considered significance. 
Acknowledgments: The authors would like to acknowledge the funding sources from NHMRC, ARC, Queensland State Government, and The University of Queensland. The authors would also like to acknowledge David Simmons (The University of Queensland) for providing virus culture system and technical support of Jason Chen (The University of Newcastle).

Author Contributions: Jie Wang and Wenyi Gu carried out the study, Chen Chen and Wenyi Gu designed and supervised the research. Wenyi Gu and Chen Chen wrote the paper.

Conflicts of Interest: The authors declare no conflict of interest.

\section{References}

1. World Health Organization. Fact Sheet No. 312; WHO: Geneva, Switzerland, 2012.

2. Grundy, S.M. Pre-diabetes, metabolic syndrome, and cardiovascular risk. J. Am. Coll. Cardiol. 2012, 59, 635-643. [CrossRef] [PubMed]

3. Ferrannini, E.; Gastaldelli, A.; Iozzo, P. Pathophysiology of prediabetes. Med. Clin. N. Am. 2011, 95, 327-339. [CrossRef] [PubMed]

4. Sabio, G.; Das, M.; Mora, A.; Zhang, Z.; Jun, J.Y.; Ko, H.J.; Barrett, T.; Kim, J.K.; Davis, R.J. A stress signaling pathway in adipose tissue regulates hepatic insulin resistance. Science 2008, 322, 1539-1543. [CrossRef] [PubMed]

5. Montminy, M.; Koo, S.H. Diabetes: Outfoxing insulin resistance? Nature 2004, 432, 958-959. [CrossRef] [PubMed]

6. Kahn, S.E. Clinical review 135: The importance of beta-cell failure in the development and progression of type 2 diabetes. J. Clin. Endocrinol. Metab. 2001, 86, 4047-4058. [PubMed]

7. Kulkarni, R.N.; Bruning, J.C.; Winnay, J.N.; Postic, C.; Magnuson, M.A.; Kahn, C.R. Tissue-specific knockout of the insulin receptor in pancreatic beta cells creates an insulin secretory defect similar to that in type 2 diabetes. Cell 1999, 96, 329-339. [CrossRef]

8. Ohsugi, M.; Cras-Meneur, C.; Zhou, Y.; Bernal-Mizrachi, E.; Johnson, J.D.; Luciani, D.S.; Polonsky, K.S.; Permutt, M.A. Reduced expression of the insulin receptor in mouse insulinoma (MIN6) cells reveals multiple roles of insulin signaling in gene expression, proliferation, insulin content, and secretion. J. Biol. Chem. 2005, 280, 4992-5003. [CrossRef] [PubMed]

9. Beith, J.L.; Alejandro, E.U.; Johnson, J.D. Insulin stimulates primary beta-cell proliferation via Raf-1 kinase. Endocrinology 2008, 149, 2251-2260. [CrossRef] [PubMed]

10. Ebina, Y.; Ellis, L.; Jarnagin, K.; Edery, M.; Graf, L.; Clauser, E.; Ou, J.H.; Masiarz, F.; Kan, Y.W.; Goldfine, I.D.; et al. The human insulin receptor cDNA: The structural basis for hormone-activated transmembrane signalling. Cell 1985, 40, 747-758. [CrossRef]

11. Belfiore, A.; Frasca, F.; Pandini, G.; Sciacca, L.; Vigneri, R. Insulin receptor isoforms and insulin receptor/insulin-like growth factor receptor hybrids in physiology and disease. Endocr. Rev. 2009, 30, 586-623. [CrossRef] [PubMed]

12. Gould, G.W.; Holman, G.D. The glucose transporter family: Structure, function and tissue-specific expression. Biochem. J. 1993, 295 Pt 2, 329-341. [CrossRef] [PubMed]

13. Thorens, B.; Sarkar, H.K.; Kaback, H.R.; Lodish, H.F. Cloning and functional expression in bacteria of a novel glucose transporter present in liver, intestine, kidney, and beta-pancreatic islet cells. Cell 1988, 55, 281-290. [CrossRef]

14. Thorens, B. Glucose transporters in the regulation of intestinal, renal, and liver glucose fluxes. Am. J. Physiol. 1996, 270, G541-G553. [CrossRef] [PubMed]

15. Colville, C.A.; Seatter, M.J.; Jess, T.J.; Gould, G.W.; Thomas, H.M. Kinetic analysis of the liver-type (GLUT2) and brain-type (GLUT3) glucose transporters in Xenopus oocytes: Substrate specificities and effects of transport inhibitors. Biochem. J. 1993, 290 Pt 3, 701-706. [CrossRef] [PubMed]

16. Thorens, B.; Wu, Y.J.; Leahy, J.L.; Weir, G.C. The loss of GLUT2 expression by glucose-unresponsive beta cells of $\mathrm{db} / \mathrm{db}$ mice is reversible and is induced by the diabetic environment. J. Clin. Investig. 1992, 90, 77-85. [CrossRef] [PubMed]

17. Thorens, B.; Guillam, M.T.; Beermann, F.; Burcelin, R.; Jaquet, M. Transgenic reexpression of GLUT1 or GLUT2 in pancreatic beta cells rescues GLUT2-null mice from early death and restores normal glucose-stimulated insulin secretion. J. Biol. Chem. 2000, 275, 23751-23758. [CrossRef] [PubMed] 
18. Ahlgren, U.; Jonsson, J.; Jonsson, L.; Simu, K.; Edlund, H. beta-cell-specific inactivation of the mouse Ipf1/Pdx1 gene results in loss of the beta-cell phenotype and maturity onset diabetes. Genes Dev. 1998, 12, 1763-1768. [CrossRef] [PubMed]

19. Waeber, G.; Thompson, N.; Nicod, P.; Bonny, C. Transcriptional activation of the GLUT2 gene by the IPF-1/STF-1/IDX-1 homeobox factor. Mol. Endocrinol. 1996, 10, 1327-1334. [PubMed]

20. Wang, H.; Maechler, P.; Ritz-Laser, B.; Hagenfeldt, K.A.; Ishihara, H.; Philippe, J.; Wollheim, C.B. Pdx1 level defines pancreatic gene expression pattern and cell lineage differentiation. J. Biol. Chem. 2001, 276, 25279-25286. [CrossRef] [PubMed]

21. Fujitani, Y.; Fujitani, S.; Boyer, D.F.; Gannon, M.; Kawaguchi, Y.; Ray, M.; Shiota, M.; Stein, R.W.; Magnuson, M.A.; Wright, C.V. Targeted deletion of a cis-regulatory region reveals differential gene dosage requirements for Pdx1 in foregut organ differentiation and pancreas formation. Genes Dev. 2006, 20, 253-266. [CrossRef] [PubMed]

22. Gu, W.; Payne, E.; Sun, S.; Burgess, M.; McMillan, N.A. Inhibition of cervical cancer cell growth in vitro and in vivo with dual shRNAs. Cancer Gene Ther. 2011, 18, 219-227. [CrossRef] [PubMed]

23. Fish, R.J.; Kruithof, E.K. Short-term cytotoxic effects and long-term instability of RNAi delivered using lentiviral vectors. BMC Mol. Biol. 2004, 5, 9. [CrossRef] [PubMed]

24. Liu, H.S.; Jan, M.S.; Chou, C.K.; Chen, P.H.; Ke, N.J. Is green fluorescent protein toxic to the living cells? Biochem. Biophys. Res. Commun. 1999, 260, 712-717. [CrossRef] [PubMed]

25. Bukrinsky, M. A hard way to the nucleus. Mol. Med. 2004, 10, 1-5. [PubMed]

26. Manjunath, N.; Wu, H.; Subramanya, S.; Shankar, P. Lentiviral delivery of short hairpin RNAs. Adv. Drug Deliv. Rev. 2009, 61, 732-745. [CrossRef] [PubMed]

27. Ter Brake, O.; Konstantinova, P.; Ceylan, M.; Berkhout, B. Silencing of HIV-1 with RNA interference: A multiple shRNA approach. Mol. Ther. 2006, 14, 883-892. [CrossRef] [PubMed]

28. Dull, T.; Zufferey, R.; Kelly, M.; Mandel, R.J.; Nguyen, M.; Trono, D.; Naldini, L. A third-generation lentivirus vector with a conditional packaging system. J. Virol. 1998, 72, 8463-8471. [PubMed]

29. Persaud, S.J.; Asare-Anane, H.; Jones, P.M. Insulin receptor activation inhibits insulin secretion from human islets of Langerhans. FEBS Lett. 2002, 510, 225-228. [CrossRef]

30. Kubota, N.; Tobe, K.; Terauchi, Y.; Eto, K.; Yamauchi, T.; Suzuki, R.; Tsubamoto, Y.; Komeda, K.; Nakano, R.; Miki, H.; et al. Disruption of insulin receptor substrate 2 causes type 2 diabetes because of liver insulin resistance and lack of compensatory beta-cell hyperplasia. Diabetes 2000, 49, 1880-1889. [CrossRef] [PubMed]

31. Srivastava, S.; Goren, H.J. Insulin constitutively secreted by beta-cells is necessary for glucose-stimulated insulin secretion. Diabetes 2003, 52, 2049-2056. [CrossRef] [PubMed]

32. Xu, G.G.; Gao, Z.Y.; Borge, P.D., Jr.; Jegier, P.A.; Young, R.A.; Wolf, B.A. Insulin regulation of beta-cell function involves a feedback loop on SERCA gene expression, $\mathrm{Ca}(2+)$ homeostasis, and insulin expression and secretion. Biochemistry 2000, 39, 14912-14919. [CrossRef] [PubMed]

33. Otani, K.; Kulkarni, R.N.; Baldwin, A.C.; Krutzfeldt, J.; Ueki, K.; Stoffel, M.; Kahn, C.R.; Polonsky, K.S. Reduced beta-cell mass and altered glucose sensing impair insulin-secretory function in betaIRKO mice. Am. J. Physiol. Endocrinol. Metab. 2004, 286, E41-E49. [CrossRef] [PubMed]

34. Melloul, D.; Ben-Neriah, Y.; Cerasi, E. Glucose modulates the binding of an islet-specific factor to a conserved sequence within the rat I and the human insulin promoters. Proc. Natl. Acad. Sci. USA 1993, 90, 3865-3869. [CrossRef] [PubMed]

35. Peers, B.; Leonard, J.; Sharma, S.; Teitelman, G.; Montminy, M.R. Insulin expression in pancreatic islet cells relies on cooperative interactions between the helix loop helix factor E47 and the homeobox factor STF-1. Mol. Endocrinol. 1994, 8, 1798-1806. [PubMed]

36. Andrali, S.S.; Sampley, M.L.; Vanderford, N.L.; Ozcan, S. Glucose regulation of insulin gene expression in pancreatic beta-cells. Biochem. J. 2008, 415, 1-10. [CrossRef] [PubMed]

37. Qiu, Y.; Guo, M.; Huang, S.; Stein, R. Insulin gene transcription is mediated by interactions between the p300 coactivator and PDX-1, BETA2, and E47. Mol. Cell. Biol. 2002, 22, 412-420. [CrossRef] [PubMed]

38. Glick, E.; Leshkowitz, D.; Walker, M.D. Transcription factor BETA2 acts cooperatively with E2A and PDX1 to activate the insulin gene promoter. J. Biol. Chem. 2000, 275, 2199-2204. [CrossRef] [PubMed]

39. Aramata, S.; Han, S.I.; Yasuda, K.; Kataoka, K. Synergistic activation of the insulin gene promoter by the beta-cell enriched transcription factors MafA, Beta2, and Pdx1. Biochim. Biophys. Acta 2005, 1730, 41-46. [CrossRef] [PubMed] 
40. Zhao, L.; Guo, M.; Matsuoka, T.A.; Hagman, D.K.; Parazzoli, S.D.; Poitout, V.; Stein, R. The islet beta cell-enriched MafA activator is a key regulator of insulin gene transcription. J. Biol. Chem. 2005, 280, 11887-11894. [CrossRef] [PubMed]

41. Janssen, R.C.; Bogardus, C.; Takeda, J.; Knowler, W.C.; Thompson, D.B. Linkage analysis of acute insulin secretion with GLUT2 and glucokinase in Pima Indians and the identification of a missense mutation in GLUT2. Diabetes 1994, 43, 558-563. [CrossRef] [PubMed]

42. Matsubara, A.; Tanizawa, Y.; Matsutani, A.; Kaneko, T.; Kaku, K. Sequence variations of the pancreatic islet/liver glucose transporter (GLUT2) gene in Japanese subjects with noninsulin dependent diabetes mellitus. J. Clin. Endocrinol. Metab. 1995, 80, 3131-3135. [PubMed]

43. Tanizawa, Y.; Riggs, A.C.; Chiu, K.C.; Janssen, R.C.; Bell, D.S.; Go, R.P.; Roseman, J.M.; Acton, R.T.; Permutt, M.A. Variability of the pancreatic islet beta cell/liver (GLUT 2) glucose transporter gene in NIDDM patients. Diabetologia 1994, 37, 420-427. [CrossRef] [PubMed]

44. Moller, A.M.; Jensen, N.M.; Pildal, J.; Drivsholm, T.; Borch-Johnsen, K.; Urhammer, S.A.; Hansen, T.; Pedersen, O. Studies of genetic variability of the glucose transporter 2 promoter in patients with type 2 diabetes mellitus. J. Clin. Endocrinol. Metab. 2001, 86, 2181-2186. [CrossRef] [PubMed]

45. McCulloch, L.J.; van de Bunt, M.; Braun, M.; Frayn, K.N.; Clark, A.; Gloyn, A.L. GLUT2 (SLC2A2) is not the principal glucose transporter in human pancreatic beta cells: Implications for understanding genetic association signals at this locus. Mol. Genet. Metab. 2011, 104, 648-653. [CrossRef] [PubMed]

46. Yuan, B.; Latek, R.; Hossbach, M.; Tuschl, T.; Lewitter, F. siRNA Selection Server: An automated siRNA oligonucleotide prediction server. Nucleic Acids Res. 2004, 32, W130-W134. [CrossRef] [PubMed]

47. Patel, D.J.; Ma, J.B.; Yuan, Y.R.; Ye, K.; Pei, Y.; Kuryavyi, V.; Malinina, L.; Meister, G.; Tuschl, T. Structural biology of RNA silencing and its functional implications. Cold Spring Harb. Symp. Quant. Biol. 2006, 71, 81-93. [CrossRef] [PubMed]

48. Asfari, M.; Janjic, D.; Meda, P.; Li, G.; Halban, P.A.; Wollheim, C.B. Establishment of 2-mercaptoethanol-dependent differentiated insulin-secreting cell lines. Endocrinology 1992, 130, 167-178. [CrossRef] [PubMed]

49. Skelin, M.; Rupnik, M.; Cencic, A. Pancreatic beta cell lines and their applications in diabetes mellitus research. ALTEX 2010, 27, 105-113. [CrossRef] [PubMed]

50. Putral, L.N.; Bywater, M.J.; Gu, W.; Saunders, N.A.; Gabrielli, B.G.; Leggatt, G.R.; McMillan, N.A. RNA interference against human papillomavirus oncogenes in cervical cancer cells results in increased sensitivity to cisplatin. Mol. Pharmacol. 2005, 68, 1311-1319. [CrossRef] [PubMed]

51. Gu, W.; Cochrane, M.; Leggatt, G.R.; Payne, E.; Choyce, A.; Zhou, F.; Tindle, R.; McMillan, N.A. Both treated and untreated tumors are eliminated by short hairpin RNA-based induction of target-specific immune responses. Proc. Natl. Acad. Sci. USA 2009, 106, 8314-8319. [CrossRef] [PubMed]

52. VanGuilder, H.D.; Vrana, K.E.; Freeman, W.M. Twenty-five years of quantitative PCR for gene expression analysis. Biotechniques 2008, 44, 619-626. [CrossRef] [PubMed]

53. Livak, K.J.; Schmittgen, T.D. Analysis of relative gene expression data using real-time quantitative PCR and the $2^{-\Delta \Delta C T}$ Method. Methods 2001, 25, 402-408. [CrossRef] [PubMed]

54. Yamada, K.; Nakata, M.; Horimoto, N.; Saito, M.; Matsuoka, H.; Inagaki, N. Measurement of glucose uptake and intracellular calcium concentration in single, living pancreatic beta-cells. J. Biol. Chem. 2000, 275, 22278-22283. [CrossRef] [PubMed]

55. Lam, N.T.; Cheung, A.T.; Riedel, M.J.; Light, P.E.; Cheeseman, C.I.; Kieffer, T.J. Leptin reduces glucose transport and cellular ATP levels in INS-1 beta-cells. J. Mol. Endocrinol. 2004, 32, 415-424. [CrossRef] [PubMed]

56. Kyriazis, G.A.; Soundarapandian, M.M.; Tyrberg, B. Sweet taste receptor signaling in beta cells mediates fructose-induced potentiation of glucose-stimulated insulin secretion. Proc. Natl. Acad. Sci. USA 2012, 109, E524-E532. [CrossRef] [PubMed]

57. Jung, C.Y.; Rampal, A.L. Cytochalasin B binding sites and glucose transport carrier in human erythrocyte ghosts. J. Biol. Chem. 1977, 252, 5456-5463. [PubMed]

(C) 2018 by the authors. Licensee MDPI, Basel, Switzerland. This article is an open access article distributed under the terms and conditions of the Creative Commons Attribution (CC BY) license (http:/ / creativecommons.org/licenses/by/4.0/). 